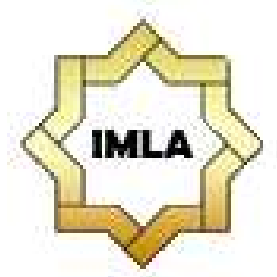

Al-Ta'rib
Jurnal Ilmiah Program Studi Pendidikan Bahasa Arab
IAIN Palangka Raya
Vol. 9, No. 2, December 2021, 215-224
p-ISSN 2354-5887 | e-ISSN 2655-5867
DOI: https://doi.org/10.23971/altarib.v9i2.3405

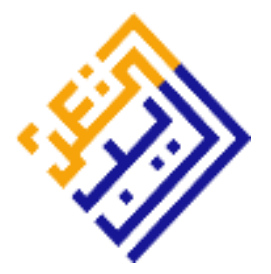

\title{
UTILIZATION OF WHATSAPP GROUP AS A COMMUNICATION MEDIUM FOR ARABIC WRITING AND TEXT MESSAGE ANALYSIS
}

\author{
Hamidah', Marsiah' ${ }^{2}$, Rodhatul Jennah ${ }^{3}$ \\ 1,2,3 Institut Agama Islam Negeri Palangka Raya, Indonesia \\ E-mail: hamidah@iain-palangkaraya.ac.id
}

\begin{abstract}
Research on WhatsApp Group as a communication medium in the learning process and the application of foreign language communication has been widely discussed by researchers. However, research on WhatsApp Group utilization as a written communication medium to learn Arabic together is still rarely studied. Therefore, this study focuses on describing the WhatsApp Group feature used to learn Arabic together in the Arabic Education Department (Pendidikan Bahasa Arab/PBA) lecturer group and analyzing the messages contained in it. This study used a qualitative descriptive approach. This study revealed several findings: the PBA lecturer group used WhatsApp for written communication using Arabic to be a medium for continuous training. Some of the topics discussed through written communication were classified into three types: first, remarks, prayers, and invitations; second, information on important academic and non-academic matters; and third, discussion about everyday life. As for the results of the analysis of the text messages written by the PBA lecturer group, it was found that the text messages written in the WhatsApp Group in terms of choosing vocabulary and sentence structure were generally correct, and there were only a few words and sentence structures that were less precise. Theoretical implications are also described in the results of this study.
\end{abstract}

Keywords: WhatsApp Group, Arabic Writing, Text Message Analysis

\section{Abstrak}

Penelitian mengenai pemanfaatan WhatsApp Group sebagai media komunikasi dalam proses pembelajaran dan penerapan komunikasi berbahasa asing sudah banyak dibahas oleh para peneliti. Namun, penelitian tentang pemanfaatan WhatsApp Group sebagai media komunikasi tertulis menggunakan bahasa Arab dengan tujuan untuk belajar bahasa Arab bersama masih jarang dikaji oleh para peneliti. Maka dari itu, penelitian ini fokus untuk mendeskripsikan pemanfaatan fitur WhatsApp Group yang digunakan untuk belajar bahasa Arab bersama pada kelompok dosen PBA serta analisis pesan yang terkandung di dalamnya. Penelitian ini menggunakan pendekatan kualitatif dengan jenis deskriptif. hasil penelitian ini mengemukakan beberapa temuan yakni bahwa kelompok dosen Prodi PBA 
menggunakan WhatsApp untuk komunikasi tertulis menggunakan Bahasa Arab dengan tujuan sebagai media latihan secara kontinu. Beberapa topik yang dibahas melalui komunikasi tertulis tersebut diklasifikasikan ke dalam tiga jenis yakni: Pertama, ucapan, doa dan undangan. Kedua, informasi hal-hal penting yang bersifat akademik maupun non akademik. Ketiga, diskusi tentang kehidupan sehari-hari. Adapun hasil analisis teks pesan yang diungkapkan oleh kelompok dosen PBA, ditemukan bahwa pesan teks yang ditulis di WhatsApp Group dari segi pemilihan kosa kata dan struktur kalimat pada umumnya tepat, dan hanya ada beberapa pemilihan kata dan struktur kalimat yang kurang tepat. Implikasi teoritis juga dijabarkan di dalam hasil penelitian ini.

Kata Kunci: Grup WhatsApp, Maharah Al-Kitabah, Analisis Pesan Text

\section{INTRODUCTION}

Information and communication technology is currently increasingly advanced. A wise alternative that the community can do in responding to it is to make the best use of the technology as a medium for improving the quality of knowledge, social and cultural life (Yoga, 2019). Advances in information and communication technology help people's lives and even become a necessity. Sources of information can be accessed quickly via the internet. Information and communication technology is integrated with people's daily lives and affects their communication patterns (Fahyuni, 2017).

Social media is one of the results of information and communication technology development, which impacts changing the way of communication from conventional to digital (Sari et al., n.d.). Social media is an online media that facilitates users to interact with others without distance and time limits and obtain and convey information quickly and economically (Cahyono, 2016).

Social media provides an alternative way for users to communicate virtually without meeting face-to-face (Xiao, 2018). Social media users can increase their existence widely by continuously updating all developments for public consumption through the status features, comments, and notes. (Watie, 2016).

Communication technology produces a variety of virtual communication features that can be applied to smartphones (Audina \& Muassomah, 2020; Mubarak et al., 2020; Timbowo, 2016). One application that facilitates this is the WhatsApp application. WhatsApp simplifies interaction through the internet network used to establish social relationships and share information, whether in interpersonal communication, group communication, or organizations familiar with the term WhatsApp Group (Fauzi, 2017; Ilmiani et al., 2020). Through WhatsApp Group, users can convey any information and discuss it in the group. The positive and negative effects of WhatsApp Group, of course, cannot be separated from how users take advantage of the results of these technological developments (Sidiq, 2019).

In education, WhatsApp is used as a communication tool and as a medium that helps the learning process run smoothly. WhatsApp Group is also used to communicate and discuss among educators (Pustikayasa, 2019). Among students, WhatsApp Group is used in the learning process, such as exchanging information, disseminating information, discussing the subject materials, assignments, and 
motivation to learn. Lecturers can also take advantage of this to share materials, information, and academic services (Afful \& Akrong, 2020).

WhatsApp Group is also used in foreign language learning (Surani \& Chaerudin, 2019). In Arabic learning, WhatsApp Group facilitates the users to practice spoken and written communication using Arabic. Both types of communication are essential elements by which other people can understand what is being conveyed (Sa'diyah, 2019b; Sa'diyah \& Alfian, 2021; Sa'diyah, 2019a; Kusumawati, 2016).

The Arabic Education Department (Pendidikan Bahasa Arab/PBA) lecturer community at higher education in Palangka Raya utilizes WhatsApp as a written communication medium using Arabic. They express everything about their daily life using Arabic through the WhatsApp Group feature. They revealed that this effort was made to develop their Arabic writing skills. They argue that their Arabic language skills will decrease drastically or disappear entirely if this is not done. Therefore, this study describes how the PBA lecturer group uses the WhatsApp Group feature to communicate in Arabic.

Research on WhatsApp Group as a medium of communication in the learning process and the application of foreign language communication has been widely discussed by other researchers. Surani and Chaerudin report that lectures using WhatsApp Group can overcome the problem of time constraints. Students can send and receive assignments in audio, video, image, and chat files (Surani \& Chaerudin, 2019). Sa'diyah reports that the WhatsApp Group feature can foster student confidence to bravely communicate verbally using Arabic (Sa'diyah, 2019b).

In addition to the statement above, Sa'diyah and Alfian describe that the WhatsApp Group feature could foster comfortable interactions among group members so that there is no awkward feeling to initiate or maintain a dialogue (Sa'diyah \& Alfian, 2021). Sa'diyah, in her other research, also reports that the status update feature in WhatsApp can also be used to train Arabic writing skills continuously and interestingly while still being guided by the learning objectives (Sa'diyah, 2019a).

Furthermore, Awada reports that WhatsApp in learning is more effective in improving students' critical writing skills and learning motivation compared to regular learning (Awada, 2016). In addition, other features such as WhatsApp diary writing can also improve students' writing skills in foreign languages (Zainab et al., 2021).

From the studies above, it inference can be drawn that researchers have widely studied the use of WhatsApp Group in foreign language learning. However, research on WhatsApp Group as a written communication medium using Arabic to learn it together is still rarely studied. Moreover, the analysis of the messages contained in written Arabic communication is also still rarely discussed. That being the case, as previously explained, this article focuses on describing the WhatsApp Group feature to learn Arabic together in the PBA lecturer group and analyzing the messages contained in it. 


\section{METHOD}

This research used a qualitative descriptive approach because it focused on describing the use of the WhatsApp Group feature to learn Arabic together in the PBA lecturer group and analyze its messages (Huberman \& Miles, 2002).

The research participants were a group of eight PBA lecturers at a higher education located in Palangka Raya, Central Kalimantan, Indonesia. The eight lecturers were recruited based on their activeness in communicating in writing using Arabic in the WhatsApp Group.

The data was extracted through interview and documentation techniques. The interview was implemented to collect data concerning how to use WhatsApp Group in applying written Arabic communication. The documentation technique was used to analyze the messages contained in Arabic written communication through WhatsApp Group.

Text messages obtained from the documentation technique were analyzed using descriptive-argumentative, which was conducted by explaining the results of sentence analysis and providing arguments at each point by analyzing the aspects of vocabulary and sentence structure. As Makrufah said, what must be considered in writing Arabic is the conformity of writing rules, such as the correct use of Arabic vocabulary, harakat, expression, and paragraph to become effective, clear, and easily understood by readers (Makrufah, 2019). The validity of Arabic writing is also adjusted to the purpose of learning to write Arabic that is being able to write in Arabic by taking into account the prevailing linguistic elements. (Rathomi, 2020). The data collected were analyzed by conducting data reduction, presentation, and conclusion drawing (Huberman \& Miles, 2002).

\section{RESULT AND DISCUSSION \\ Utilization of WhatsApp Group as Arabic Writing Media}

The PBA lecturers utilize WhatsApp Group for written communication in Arabic. They revealed that the purpose was to train their Arabic language skills, especially writing skills (maharah kitabah). On the other hand, it was done so that their Arabic language skills would not be lost or forgotten due to the lack of application of the language. WhatsApp Group also has a significant advantage; messages or writings in it will be there permanently if we do not delete them. It is undoubtedly helpful so that the messages can be re-read and corrected so the members can use the correct Arabic written language.

As Makrufah said, Arabic writing skills are positioned as a medium of written Arabic communication by expressing thoughts or ideas with specific meanings to the intended readers to comprehend. Writing is timeless so that it can be read at any time without being limited by space and time (Makrufah, 2019). On the other hand, the communication in Arabic writing can then be corrected according to the applicable rules in Arabic. It has implications for improving other Arabic language skills such as language elements, such as vocabulary (mufradath) and grammar (tarkib), and other skills such as listening (istima'), speaking (kalam), and reading (qira'ah).

On another occasion, PBA lecturers revealed that the text written and sent to WhatsApp Group was a natural and authentic message or, in other words, a message that is delivered according to reality on the field, not intentionally 
created. The message is written in the form of a redaction that must be disclosed and answered. In writing messages, lecturers put Arabic writing with vocabulary and sentence structure skills they have mastered. If there is an unknown vocabulary or sentence structure, the lecturers can directly look it up in the offline and online dictionary application or Google via smartphones. It becomes a convenience for them, and it can improve the quality of their Arabic language skills.

The efforts made by the lecturers in searching for vocabulary and seeking information or knowledge about sentence structures that have not been understood are similar to those performed by previous researchers. Daeng et al. report that smartphones and the internet allow them to learn new things anywhere and anytime, enabling people to access information quickly (Daeng et al., 2017). The convenience of smartphones can motivate students to improve their foreign language skills because it is simple, practical, and economical (Barakati, n.d.).

WhatsApp is an effective communication medium in establishing social relationships and sharing information, whether it is interpersonal, groups, or organizations (Fauzi, 2017). The utilization of WhatsApp Group among PBA lecturers in written communication has also previously been carried out by educators (Shidiq \& Warnilah, 2019), and it is also used as a medium of communication and discussion among employees in a company to help improve the effectiveness of their performance (Anjani et al., 2018). Practice and interaction in WhatsApp Group can improve foreign language skills virtually (Surani \& Chaerudin, 2019), including Arabic (Arifin et al., 2021; Ilmiani et al., 2020; Yahya et al., 2021).

The written communication in Arabic conducted by the lecturers is about information and daily communication related to joint activities both on and offcampus. The topics of written communication are expressions of joy, sorrow, prayers, invitations, notifications, and discussions. Remarks and prayers frequently conveyed in WhatsApp Group are per what happened at that time, such as congratulations on achieving an academic degree, prayers for ease and smoothness in a matter, gratitude for assistance both in material and non-material, and apologies for forgetfulness and neglect.

Invitations or information often conveyed in WhatsApp Group are regular monthly meetings, periodic visits to orphanages notifications, exam schedules notification, and forwarded information regarding important matters. The frequent conversations in WhatsApp Group are the preparation of both academic and non-academic activities, the communication for the solution of a problem during an important event, such as technical problems on computers and the internet, the menus that must be provided, the study program's accreditation, the student achievements in academics, and other non-formal talks such as clothing, menu, advice on health, and world breaking news.

From the description, it can be inferred that WhatsApp is used to convey joy and sorrow, prayers and apologies written in Arabic. WhatsApp can also be applied for various invitations, information, and discussions of anything written in Arabic. As Setiawan said, WhatsApp is used to stream information or messages to help 
solve human problems (activities) so that communication objectives are achieved (Setiawan, 2018).

WhatsApp is beneficial in improving the ability to write Arabic continuously. As Nasution said, information and communication technology media are made to facilitate people to explore and exchange information which is then used to develop their progress (Nasution, 2011).

As with the PBA lecturer group, other professional groups also use WhatsApp Group to support their profession, such as journalists worldwide. They regularly use WhatsApp in their professional practice, strengthen their commitment in their field and contribute to the good of society. This application generates story ideas and helps people find and communicate with other sources (McIntyre \& Sobel, 2019). Consequently, WhatsApp is beneficial for helping professional groups facilitate work in communicating, writing skills, supporting, and motivating each other.

\section{Text Message Analysis}

As previously stated, written communication using Arabic carried out by the PBA lecturer group is classified into three types: first, remarks, prayers, and invitations; second, information on important academic and non-academic matters; and third, discussion about everyday life. The messages through WhatsApp Group were then analyzed by looking at the accuracy of the vocabulary selection and the accuracy of the sentence structure.

The choice of vocabulary and sentence structure in text messages written in Arabic was generally correct. The following is an example of a text message written in Arabic:

$$
\text { نزن نريد أن نزور دار اليتامى، ربما في شهر فبرايير أو قبل رمضان. }
$$

The text message above belongs to the notification type. The author informed his friends that the next regular visit to the orphanage would be held before Ramadan. The vocabulary used was also appropriate. The sentence structure in this message was accurate, using the pattern of jumlah ismiyah, which begins with isim dhamir as mubtada and khabar and the form of jumlah fi'liyah which consists of fi'il, fa'il, and maf'ul bih. Another example of Arabic writing can be seen in the sentence below:

$$
\text { العلام عليكم ورحمة الله وبركاته. نرجو حضوركم وأسرتكم في اجتماعة شهرية لمحاضري قسم تعليم اللغة }
$$

The message above belongs to the invitation type. The invitation above contained requests for attendance from PBA lecturers and their respective families at regular monthly meetings at a predetermined time and place. The vocabulary used in the sentence was accurate. It was started with greetings, and then it conveyed the contents of the message. The sentence structure used was also appropriate. The first sentence used the jumlah ismiyyah pattern, and the second used the pattern of jumlah fi'liyyah, which consists of fi'il, fa'il, and maf'ul bih.

As it is seen from the accuracy of the vocabulary selection, some inappropriate vocabulary was found, such as the words بو an دكتور.. in دكتور ind The 
appropriate word should be دكتورة.. This error is influenced by the languages commonly used by PBA lecturers in daily life, Indonesian or regional languages. It happened in the word كيف in the sentence كيف نسلم صدقتك إليه. The proper sentence should be لو سمحت سنسلم صدقتك إليها Which should be written as إنشاء الله

From the accuracy of the sentence structure, the messages written were generally correct. There were only a few errors that needed to be corrected, such as سهل الله في امتحانك. In the example, an object must exist (maf'ul bih) to complete the sentence. Therefore, the correct sentence is سهل الله لك الامتحان. The following example of an error was the sentence فمن يرد أن يعطيها ضعها أمام مكتبي. The appropriate sentence

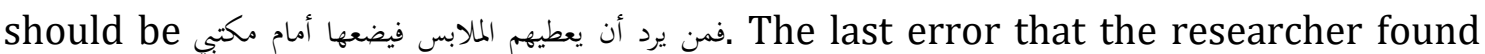
was in the following sentence ربما لم ينخفض الألم فتحمله إلى الطبيب. The correct sentence should be إن لم ينحفض الألم فخذه إلى الطبيب.

From the results of this study, a conclusion can be drawn that, first, WhatsApp Group can help expedite work and communication outside of work. Second, by practicing Arabic writing continuously in WhatsApp Group, PBA lecturers' vocabulary will always be maintained and will not be easily forgotten. Their Arabic language skills will increase not only in writing but also in speaking. The more they use WhatsApp Group to communicate Arabic, the more they train and improve their abilities. Madge et al. say that interactive applications like WhatsApp can increase the homogeneity of learning success (Madge et al., 2019). Other findings also show that a combination of traditional approaches and technology can support work well (Haniah, 2014; Yavuz, 2016). The emergence of WhatsApp as a social media opens several opportunities for learners to change their educational journey for the better (Madge et al., 2019).

\section{CONCLUSION}

This study describes how the PBA lecturer group utilizes the WhatsApp Group feature to communicate using Arabic and analyzes its messages. From the results of this study, it is found that the PBA lecturer group used WhatsApp for written communication using Arabic as a medium for continuous practice. Some of the topics discussed through written communication are classified into three types: first, remarks, prayers, and invitations; second, information on important academic and non-academic matters; and third, discussion about everyday life. As for the results of the analysis of the text messages expressed by the PBA lecturer group, it is found that the text messages written in WhatsApp Group were generally correct in terms of choosing vocabulary and sentence structure, and there are only a few words and sentence structures that are less precise. This research implies that WhatsApp Group can facilitate groups of foreign language lecturers to improve their foreign language skills through writing text messages.

\section{REFERENCE}

Afful, B., \& Akrong, R. (2020). WhatsApp and academic performance among undergraduate students in Ghana: Evidence from the University of Cape 
Coast. Journal of Education for Business, 95(5), 288-296. https://doi.org/10.1080/08832323.2019.1644276

Anjani, A., Ratnamulyani, I. A., \& Kusumadinata, A. A. (2018). Penggunaan Media Komunikasi Whatsapp Terhadap Efektivitas Kinerja Karyawan. JURNAL KOMUNIKATIO, 4(1), Article 1. https://doi.org/10.30997/jk.v4i1.1211

Arifin, Z., Febriani, S. R., \& Anasruddin, A. (2021). Using Bloom's Taxonomy in Arabic Learning Media to Elevate Student's Writing in Covid-19 Situation. Al-Ta'rib: Jurnal Ilmiah Program Studi Pendidikan Bahasa Arab IAIN Palangka Raya, 9(1), 1-12. https://doi.org/10.23971/altarib.v9i1.2530

Audina, N. A., \& Muassomah, M. (2020). Instagram: Alternatif Media dalam Pengembangan Maharah Al-Kitabah. Al-Ta'rib: Jurnal Ilmiah Program Studi Pendidikan Bahasa Arab IAIN Palangka Raya, 8(1), 77-90. https://doi.org/10.23971/altarib.v8i1.1986

Awada, G. (2016). Effect of WhatsApp on critique writing proficiency and perceptions toward learning. Cogent Education, 3(1), 1264173. https://doi.org/10.1080/2331186X.2016.1264173

Barakati, D. P. (n.d.). UNIVERSITAS SAM RATULANGI FAKULTAS SASTRA MANADO. 13.

Cahyono, A. S. (2016). Pengaruh Media Sosial Terhadap Perubahan Sosial Masyarakat Di Indonesia. Jurnal PUBLICIANA, 9(1), 140-157.

Daeng, I. T. M., Mewengkang, N. N., \& Kalesaran, E. R. (2017). Penggunaan Smartphone Dalam Menunjang Aktivitas Perkuliahan Oleh Mahasiswa Fispol Unsrat Manado. ACTA DIURNA KOMUNIKASI, 6(1), Article 1. https://ejournal.unsrat.ac.id/index.php/actadiurnakomunikasi/article/vie $\mathrm{w} / 15482$

Fahyuni, E. F. (2017). Teknologi, Informasi, Dan Komunikasi (Prinsip Dan Aplikasi Dalam Studi Pemikiran Islam). Umsida Press. https://doi.org/10.21070/2017/978-979-3401-60-7

Fauzi, R. (2017). Perubahan Budaya Komunikasi pada Pengguna Whatsapp di Era Media Baru. Jurnal Ilmu Komunikasi Efek, 1(1), 265273. https://doi.org/10.32534/jike.v1i1.44

Haniah, H. (2014). Pemanfaatan Teknologi Informasi dalam Mengatasi Masalah Belajar Bahasa Arab. Al-Ta'rib: Jurnal Ilmiah Program Studi Pendidikan Bahasa Arab IAIN Palangka Raya, 2(1). https://doi.org/10.23971/altarib.v2i1.588

Huberman, M., \& Miles, M. B. (2002). The Qualitative Researcher's Companion. SAGE.

Ilmiani, A. M., Marsiah, M., Rahmah, Y., \& Mubarak, M. R. (2020). WhatsApp Group to Optimize the Mahārah Istimā' Learning During the Covid-19 Pandemic. ALSINATUNA, 6(1), 16-34. https://doi.org/10.28918/alsinatuna.v6i1.2841

Kusumawati, T. I. (2016). KOMUNIKASI VERBAL DAN NONVERBAL. 6(2), 16. 
Madge, C., Breines, M. R., Dalu, M. T. B., Gunter, A., Mittelmeier, J., Prinsloo, P., \& Raghuram, P. (2019). WhatsApp use among African international distance education (IDE) students: Transferring, translating, and transforming educational experiences. Learning, Media, and Technology, 44(3), 267-282. https://doi.org/10.1080/17439884.2019.1628048

Makrufah, Y. K. (2019). KITABAH SEBAGAI MEDIA KOMUNIKASI TULISAN. 8.

McIntyre, K., \& Sobel, M. (2019). How Rwandan Journalists Use WhatsApp to Advance Their Profession and Collaborate for the Good of Their Country. Digital Journalism, 7(6), 705-724. https://doi.org/10.1080/21670811.2019.1612261

Mubarak, M. R., Wahdah, N., Ilmiani, A. M., \& Hamidah, H. (2020). Penggunaan Vlog Dalam Pembelajaran Mahārah Kalām. Al Mi'yar: Jurnal Ilmiah Pembelajaran Bahasa Arab dan Kebahasaaraban, 3(1), 109-126. https://doi.org/10.35931/am.v3i1.209

Nasution, Z. (2011). KONSEKUENSI SOSIAL MEDIA TEKNOLOGI KOMUNIKASI BAGI MASYARAKAT. REFORMASI, https://jurnal.unitri.ac.id/index.php/reformasi/article/view/9

Pustikayasa, I. M. (2019). Grup WhatsApp Sebagai Media Pembelajaran. Widya Genitri: Jurnal Ilmiah Pendidikan, Agama Dan Kebudayaan Hindu, 10(2), 5362. https://doi.org/10.36417/widyagenitri.v10i2.281

Rathomi, A. (2020). Maharah Kitabah Dalam Pembelajaran Bahasa Arab. Tarbiya Islamica, 1(1), 1-8.

Sa'diyah, H. (2019a). Mahârah Al-Kitâbah Bagi Mahasiswa Melalui Update Status Pada Media Whatsapp. AL-AF'IDAH: Jurnal Pendidikan Bahasa Arab Dan Pengajarannya, 3(2), 23-37. https://doi.org/10.52266/al-afidah.v3i2.305

Sa diyah, H. (2019b). Upaya menumbuhkan self-confidence berbicara Bahasa Arab mahasiswa melalui grup Whatsapp. Al-Mi'yar, 2(2), 149-164.

Sa`diyah, H., \& Alfian, M. I. (2021). WhatsApp small groups sebagai media pembelajaran maharah al-kalam di masa daring. Arabia: Jurnal Pendidikan Bahasa Arab, 13(1), 1-22.

Sari, A. C., Hartina, R., Awalia, R., Irianti, H., \& Ainun, N. (n.d.). KOMUNIKASI DAN MEDIA SOSIAL. 10.

Setiawan, D. (2018). Dampak Perkembangan Teknologi Informasi dan Komunikasi Terhadap Budaya. JURNAL SIMBOLIKA: Research and Learning in Communication Study, 4(1), 62-72.

Shidiq, M. J., \& Warnilah, A. I. (2019). Analisis Penerimaan Grup Whatsapp Sebagai Media Komunikasi dan Diskusi Guru. IJCIT (Indonesian Journal on Computer and Information Technology), 4(2), Article 2. https://doi.org/10.31294/ijcit.v4i2.5478 
Sidiq, R. (2019). Pemanfaatan Whatsapp Group Dalam Pengimplementasian NilaiNilai Karakter Pancasila Pada Era Disrupsi. Puteri Hijau: Jurnal Pendidikan Sejarah, 4(2), 145-154. https://doi.org/10.24114/ph.v4i2.16304

Surani, D., \& Chaerudin, A. R. (2019). Pemanfaatan Media WhatsApp Grouping dalam Peningkatan Kemampuan Bahasa Inggris Ekonomi Mahasiswa Fakultas Ekonomi dan Bisnis. Tarbawi: Jurnal Keilmuan Manajemen Pendidikan, 5(02), 155-172. https://doi.org/10.32678/tarbawi.v5i02.2050

Timbowo, D. (2016). Manfaat Penggunaan Smartphone Sebagai Media Komunikasi (Studi pada Mahasiswa Jurusan Ilmu Komunikasi Fakultas Ilmu Sosial dan Politik Universitas Sam Ratulangi). ACTA DIURNA KOMUNIKASI, 5(2), Article 2. https://ejournal.unsrat.ac.id/index.php/actadiurnakomunikasi/article/vie $\mathrm{w} / 11719$

Watie, E. D. S. (2016). Komunikasi dan Media Sosial (Communications and Social Media). Jurnal The Messenger, 3(2), 69-74. https://doi.org/10.26623/themessenger.v3i2.270

Xiao, A. (2018). KONSEP INTERAKSI SOSIAL DALAM KOMUNIKASI, TEKNOLOGI, MASYARAKAT. Jurnal Komunika: Jurnal Komunikasi, Media Dan Informatika, 7(2), 94-99. https://doi.org/10.31504/komunika.v7i2.1486

Yahya, M., Maftuhati, M., Mustofa, A. H., \& Arifa, Z. (2021). Online-Based Arabic Learning Management During the Covid-19 Pandemic Era: Plan, Implementation and Evaluation. Al-Ta'rib: Jurnal Ilmiah Program Studi Pendidikan Bahasa Arab IAIN Palangka Raya, 9(1), 85-98. https://doi.org/10.23971/altarib.v9i1.2505

Yavuz, F. (2016). Do Smartphones Spur or Deter Learning: A WhatsApp Case Study. International Journal of Educational Sciences, 15(3), 408-415. https://doi.org/10.1080/09751122.2016.11890551

Yoga, S. (2019). Perubahan Sosial Budaya Masyarakat Indonesia Dan Perkembangan Teknologi Komunikasi. Jurnal Al-Bayan: Media Kajian Dan Pengembangan Ilmu Dakwah, 24(1), Article 1. https://doi.org/10.22373/albayan.v24i1.3175

Zainab, I., Jaya, G. B., \& Artini, L. P. (2021). Meningkatkan Keterampilan Menulis Peserta Didik Melalui Whatsapp Diary Writing. Indonesian Gender and Society Journal, 1(2), 60-68.

\section{COPYRIGHT NOTICE}

Authors retain copyright and grant the journal right of first publication with the work simultaneously licensed under a Creative Commons Attribution 4.0 International License that allows others to share the work with an acknowledgement of the work's authorship and initial publication in this journal.

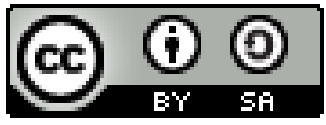

Jurnal Ilmiah Program Studi Pendidikan Bahasa Arab IAIN Palangka Raya Vol. 9, No. 2 |215-224 Al-Ta'rib | p-ISSN 2354-5887 | e-ISSN 2655-5867 